\title{
Everyday Gratitude in Times of Uncertainty
}

\author{
Carol Wittmeyer (St. John Fisher College)
}

KEYWORDS: Leadership, Family Business, human resources, Customer relations.

It's worth reiterating: although Election Day has come and gone, political upheaval and uncertainty are far from over. And rather than drawing to a close, all evidence points to the Coronavirus pandemic gaining momentum before the arrival of a scarce vaccine requiring a demanding supply chain. Add ongoing (and perhaps escalating) racial tensions and economic disruption from which it will takes months and years to recover, and it's no wonder so many of us are struggling to cultivate a positive outlook -and to help our employees, colleagues, students and families manage successfully through this time of complex, inter-related crises.

As Dr. Claudia Binz Astrachan uncovered through her recent research with several colleagues, and detailed in her article, Research Reveals How Business Families Have Coped With COVID-19, (https://familybusiness.org/content/research-revea Is-how-business-families-have-coped-with-

covid-19) we are learning that "increased focus on employee safety and well-being, and the need to critically evaluate and adjust existing business models" must guide our approach. She highlights several key strategies for managing through crisis, including "securing business continuity," paying special attention to "employee well-being and mental health," determining whether your approach is to return to an "old normal" or to build resilience as a "new normal" company, "effectively managing the family shareholder group," and effectively and quickly adjusting best practices using "Family-Practice Fit" principles.

As I pause to consider Dr. Binz Astrachan's thoughts on building resiliency, the six characteristics of family resilience as cited by Dr. Forma Walsh in "Strengthening Family Resilience" (Third Edition, 2015) also come to mind:

1. Avoid feeling helpless by viewing stress and setbacks in a positive light.

2. Be appreciative and show gratitude.

\section{Maintain a staunch acceptance of reality.}

4. Possess a deep belief that life is meaningful, buttressed by strongly held values.

5. Cultivate an uncanny ability to improvise.

6. Strengthen the ability to self-govern.

\section{A powerful leadership strategy}

The insights into family businesses and Covid, in concert with Dr. Walsh's observations, provide a compelling platform for additional consideration. That is-however counterintuitive it may be in the face of multiple crises-a deliberate focus on gratitude is a powerful and effective leadership strategy. Whether societal construct or deeply rooted in our biological development, gratitude nurtures positive relationships and individual satisfaction. Long the purview of religious leaders and philosophers, gratitude is emerging as a key tenet in understanding business success. Indeed, recent research suggests that gratitude is one of the most powerful strategies we have to be resilient and effective leaders. Our everyday experience confirms it. Recognition that we could not be where we are in life without the contributions of others feels good to acknowledge and to receive.

Common sense tells us that cultivating a culture of gratitude is a powerful motivator, and science provides evidence of its efficacy as a leadership strategy. A recent study conducted by the American Psychological Association (APA) indicated that more than half of all employees were considering looking for new jobs because they felt undervalued. The Society for Human Resources Management recently reported, "more than half of human-resource managers say showing appreciation for workers cuts turnover, and $49 \%$ believe it increases profit. When employees feel appreciated and understand that what they do is truly important, they are more motivated to go above and beyond their job descriptions to make a difference for their companies."
Copyright $@ 2020$ The Authors. Entrepreneur \& Innovation Exchange is published at EIX.org. This is an open access article under the terms of the Creative Commons Attribution-NoDerivs License, which permits use and distribution in any medium, provided the original work is properly cited and no modifications or adaptations are made. View EIX.org Authorship Terms at https://eix.org/terms
FamilyBusiness 
When money is not the primary motivating factor, it's all about how people feel. My observations suggests this is especially true for family members in the business.

In a recent meeting of 125 family business owners, I asked how many owners had some type of regular evaluation/feedback sessions with non-family members working in the business. Every hand went up. Then I asked how many gave feedback to family employees. Few hands went up. That's not surprising. In our busy worlds, we tend to focus on giving feedback to our nonfamily employees. Perhaps that is because we take family employees' loyalty for granted. As we negotiate the often-tumultuous relationships in family businesses, this time of intense crisis may remind us that we need to look more closely at all employees and ask if we can improve our relationships by being more grateful. Or perhaps it's that we need to be more deliberate and strategic about expressing our gratitude.

\section{Effective gratitude}

While you may think gratitude involves a simple thank you, to make it effective, Dr. Mark Goulston suggests that there are three parts to what he calls a "Power Thank You."

1. Be specific. Describe the specific behaviors for which you are grateful. For example, "Sara, thank you for going out of your way to deliver Ms. Smith's special order yesterday and making sure the fit was right. Because of your thoughtfulness, she called to say how pleased she was and that she recommends our business to everyone in her apartment building. Your attention to people and to detail is what differentiates us from the big chains."

2. Be personal. Tell them what their actions meant to you. "When you went to extra lengths to help assure that a costumer was satisfied, it said to me that you care passionately about our family business. Sara, I want you to know how much it means to me that I get to come to work knowing you are doing everything you can to keep our family dream alive and serve our customers to the best of our abilities. Excellent service is at the top of our values and I'm grateful to you for embodying that in all that you do."

3. Acknowledge the impact. Recap their personal efforts and sacrifices. "I know that when you dropped what you were doing to turn your attention to Ms. Smith's delivery, that required you to work late and that you had to rearrange your family dinner plans. And you did not complain. That kind of gesture is symbolic, Sara, and helps us all to stay motivated."

\section{Building a culture of gratitude}

Expressing gratitude generates its own momentum. Once you start using effective expressions of gratitude as a genuine and strategic leadership tool, others will begin to do the same. Leadership expert Dr. Christine Riordan suggests that effective leaders who incorporate gratitude into their leadership build more effective teams. Employees (and, as mentioned above, family members) are recognized for the behaviors that help them be better contributors. In turn, as they incorporate expressing gratitude toward others, they become better colleagues to those around them.

In harnessing the power of gratitude, there are a few simple techniques to build gratitude aptitude as both a practice and a leadership strategy:

1. Gratitude Journal. Keep a journal in your nightstand or on the corner of your desk. Whether you jot down 2-3 things for which you're grateful before nodding off or start the day with a reminder of how others have contributed to your journey, developing a sense of gratitude becomes a daily habit.

2. Gratitude Letter/Meeting. Think about who made a significant contribution that you might not have fully acknowledged at the time. My thoughts turned to my doctoral advisor. After losing one daughter to a rare disease, his second daughter was killed in a tragic car accident. I thought about what this must have felt like to him and what I could do for him. While I couldn't truly appreciate the magnitude of his loss, I wanted him to know he had made a profound difference in my life for which I was deeply grateful. I reflected on all of the wonderful opportunities (great jobs, wonderful colleagues and exciting travel) made possible because of earning a doctorate. And I knew earning that degree would not have happened without him, so I collected my thoughts and shared my gratitude in a letter to him. Weeks later, he wrote back and said that the letter was one of the most significant acknowledgements he had received and that it came at a particularly important time 
in his life. In reading his note there was a palpable sense of reciprocal gratitude. I could feel his tears with each word, and it was truly one of the best moments in my life.

3. Gratitude Session. My favorite session with a family business client was an event we organized for the first family meeting after the death of the Ted, a G2 former CEO, dad to G3 and granddad to G4. Following a multimedia tribute to Ted, the G3 and G4 generations got together and talked about all the ways they were grateful for Ted. Next, each generation worked together to identify their gratitude for the other generation. Finally, in one of the most powerful sessions I have experienced, each group selected a spokesperson and expressed their gratitude to the other generation:

G3 to G4: "We are grateful for the sincere engagement of G4. They are all over the nation and come together to be unified effective stewards of our future. We are grateful for their diversity and their respect for one another. We are grateful to their commitment to our family values, including recognizing when they needed to be revisited to be current."

G4 to G3: "We are grateful for your willingness to go through hard things together and never give up. We are grateful for your ability to enthusiastically make room for us in our governance and become more flexible as you got older. Additionally, G4 gave gratitude to each member of the G3s which demonstrated their deep understanding and appreciation for each member."

\section{A chance to strengthen alignment}

In closing, Dr. Binz Astrachan notes that a crisis often "acts like a proving ground ... exacerbat(ing) any tears in the fabric of the family or the business. Investing in family alignment and cohesion has never been more important." Indeed, not only is "listening with the intent to understand" a key to fostering meaningful relationships, I want to add that the same applies in delivering messages. Our expression of gratitude must be authentic, and shared with the intent of building greater understanding, empathy and commitment.

While the realities of the Covid-19 pandemic have dictated more time alone, perhaps the "silver lining" is that we have become more attuned to the value of relationships. Whether together in person or connecting on Zoom, as Thanksgiving nears, we tend naturally to gravitate toward feelings of gratitude. I encourage each of you, and all of us, to consider the power, the joy, and, yes, the love in expressing our gratitude to those who have made a difference in our lives. 